ENTREPRENEURSHIP AND SUSTAINABILITY ISSUES

ISSN 2345-0282 (online) http://jssidoi.org/jesi/

2019 Volume 7 Number 2 (December)

http://doi.org/10.9770/jesi.2019.7.2(48)

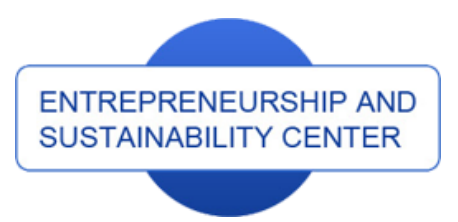

Publisher

http://jssidoi.org/esc/home

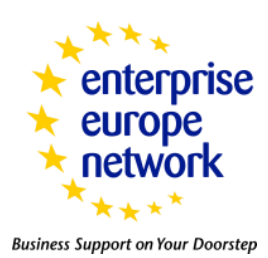

CASPA

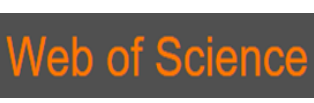

\title{
BUSINESS SCALING THROUGH OUTSOURCING AND NETWORKING: SELECTED CASE STUDIES
}

\section{Khayrolla Mussapirov ${ }^{1}$, Jeksen Djalkibaev ${ }^{2}$, Gulnara Kurenkeyeva ${ }^{3}$, Aizhan Kadirbergenova ${ }^{4}$, Mariana Petrova $^{5}$, Lyailya Zhakypbek ${ }^{6}$}

1,2,3,4,6 Almaty Management University, Graduate School of Business Rozybakiev Street 227, Almaty 050060, Kazakhstan

${ }^{5}$ St. Cyril and St. Methodius University of Veliko Tarnovo, 5000 T.Tarnovski 2 Street, Veliko Tarnovo, Bulgaria

\author{
E-mails:Imusapirov@mail.ru, ${ }^{2}$ jeksen.kz@gmail.com,${ }^{3}$ kurenkeyeva@almau.edu.kz, \\ ${ }^{4}$ Aizhan.kadirbergenova@almau.edu.kz, ${ }^{5}$ m.petrova@ts.uni-vt.bg , ${ }^{6}$ l.zhakypbek@almau.edu.kz
}

Received 16 August 2019; accepted 6 November 2019; published 15 December 2019

\begin{abstract}
A business scaling on the basis of outsourcing and creation of an entrepreneurial network is discussed in this article.The network allows to expand the resource capabilities of its member enterprises. This aspect seems significant in the case of the inadequacy of researches that consider the period of the emergence of network structures. The proposed nanocorporation model assumes a network of independent, specialized supplier companies with a small coordinating integrator. In nanocorporations, the core company outsources most of its functions and develops its main competency, specializing in planning, corporate management, and marketing. An expanding affiliate business network provides fast business growth, minimization of costs, high mobility. The article examines the process of creating an entrepreneurial network using the example of three Kazakhstani small and medium-sized businesses. On the basis of the analysis, the stages of the decision-making sequence are proposed while creating a network. Case study method is used as the main one in the work.
\end{abstract}

Keywords: network; outsourcing; nanocorporation; entrepreneurship, small and medium business (SME)

Reference to this paper should be made as follows: Mussapirov, K., Djalkibaev, J., Kurenkeyeva, G., Kadirbergenova, A., Petrova, M., Zhakypbek, L. 2019. Business scaling through outsourcing and networking: selected case studieS, Entrepreneurship and Sustainability Issues, 7(2), 1480-1495. http://doi.org/10.9770/jesi.2019.7.2(48)

JEL Classifications: M13, L25, L26 


\section{ENTREPRENEURSHIP AND SUSTAINABILITY ISSUES}

ISSN 2345-0282 (online) http://jssidoi.org/jesi/

2019 Volume 7 Number 2 (December)

http://doi.org/10.9770/jesi.2019.7.2(48)

\section{Introduction}

The activity of business entities present on the market represents the key instrument triggering the economic growth and innovativeness of the economy. A lot of businesses are looking for innovative ways to improve efficiency and maintain competitive advantage in order to survive (Tvaronavičiené, Razminienė 2017; Eddelani et al. 2019; Prodani et al. 2019; Amraoui et al., 2019).

Innovative enterprises, including start-ups defined in various ways, which through their innovative undertakings that concentrate on seeking their unique developmental path, can quickly dominate the national and global markets, therefore they are of considerable importance for the economy. The reason why new and small businesses have become key players in the innovation process has been their ability to identify and exploit business opportunities which emerge as a result of technological, competitive and market developments (Hlushko et al, 2015; Islamgaleyev \& Uruzbayeva, 2018).

Modern technologies aimed at improving algorithms and methods of data collection, storage and processing are tailoring the quality of output information for the end user, including the development of artificial intelligence systems, whose analytical modules and methods are used to filter out unnecessary information and search for dependencies between socio-economic processes (Dyachenko at al, 2018; Dellis et al., 2016; Nenkov et al, 2016; Petrova et al, 2018; Nenkov et al, 2017; Tvaronavičienė, 2017; Tumalavičius et al, 2017).

Nowadays there are platforms, information and communication technologies that can be rented when they are needed. This has undermined the strong feedback between fixed costs and output, which determine economies of scale due to the large scale typical of large corporations. According to experts small firms and their networks occupy niche markets, competing with large companies, which are weighed down by many years of investment in large-scale production and distribution networks (Hemand \& Kevin, 2018; Kolodiziev \& Boyko, 2015; Koval \& Pukała, 2017; Ponomarenko \& Gontareva, 2017; Bogomolov at al, 2018).

Researchers have studied scalability in 90 Scandinavian companies, as well as the experience of several wellknown companies, including Google, Apple and Groupon. (Nielsen and Lund, 2018). In the the study, they identified five models (patterns) on the basis of which companies can achieve business scalability: through new distribution channels; through the release of bandwidth limitations, overcoming bottlenecks; through the multiplicity of the role of customers and other partners; through creating a common platform. Finally, the fifth model for scalability and business growth, which is in the focus of this study, is attracting third-party investments in the process of outsourcing various types of activities when external partners of the core company become participants in the same business model (network).

The subject of this study is the emergence of an entrepreneurial network based on outsourcing. They also contribute to its innovation and gaining a competitive advantage on the market (Pukala et al, 2018; Pukala \& Petrova, 2019; Galaso, Kováŕík, 2018).

This aspect of the study of the emergence and origin of network business structures with a focus on their entrepreneurial character and managerial innovations is poorly covered in the literature. More attention is paid to a retrospective survey of the emergence of individual firms, or a description of product or technological innovations (Damanpour \& Aravind, 2012; Nievesatal, 2018). 


\section{Entrepreneurial networks and nanocorporation model}

A number of studies confirm that network management is an effective form of economic coordination that contrasts and competes with markets and vertical hierarchies (Dedeurwaerdere at al, 2007). The development of network structures and cooperation allows firms to be more competitive by overcoming limitations - both traditional hierarchical organizations and spontaneous market regulation.

In this study, the management approach based on theories of strategic management and interorganizational relations is taken as the basis, which does not exclude intersections with other theoretical platforms. Networks are seen as a mechanism of "intercompany coordination, characterized by informal social systems, compared with bureaucratic structures within firms and formal contractual relationships between them" (Jones et al, 1997). At the same time, it is assumed that network entities, successfully operating in an uncertain and competitive environment, can significantly provide control control without controlling ownership of assets.

In terms of content, ordinary small and medium-sized businesses mainly consist of routine actions devoid of novelty in disseminating "well-known products to well-known customers". This article is about an entrepreneurial firm and a network focused on business scaling; the focus of the study is the innovative nature of the activity, a significant change in the organizational context and redefinition of property.

At the first stage, the enterprise network integrator company itself reaches a certain level of operational efficiency, implements advanced working methods, creates a certain brand. This allowsto attract new members, conclude franchise agreements and have leverage over the participants in the franchise network, without controlling the ownership of its members. Researchers call such networks asymmetric hierarchical networks based on formal contracts, a coordinating apparatus, and a system of rewards and fines (Grandori, 2001).

It is important for an integrating company to find the right balance between excellent competence in industry technology, brand building, on the one hand; and the integrating role in the network based on franchise agreements and effective corporate management, on the other hand (T-model of a network enterprise, Figure 1). It is in the fulfillment of this dual role by the integrating company that it is difficult to imitate abilities that create sustainable competitive advantages and accelerated network growth.

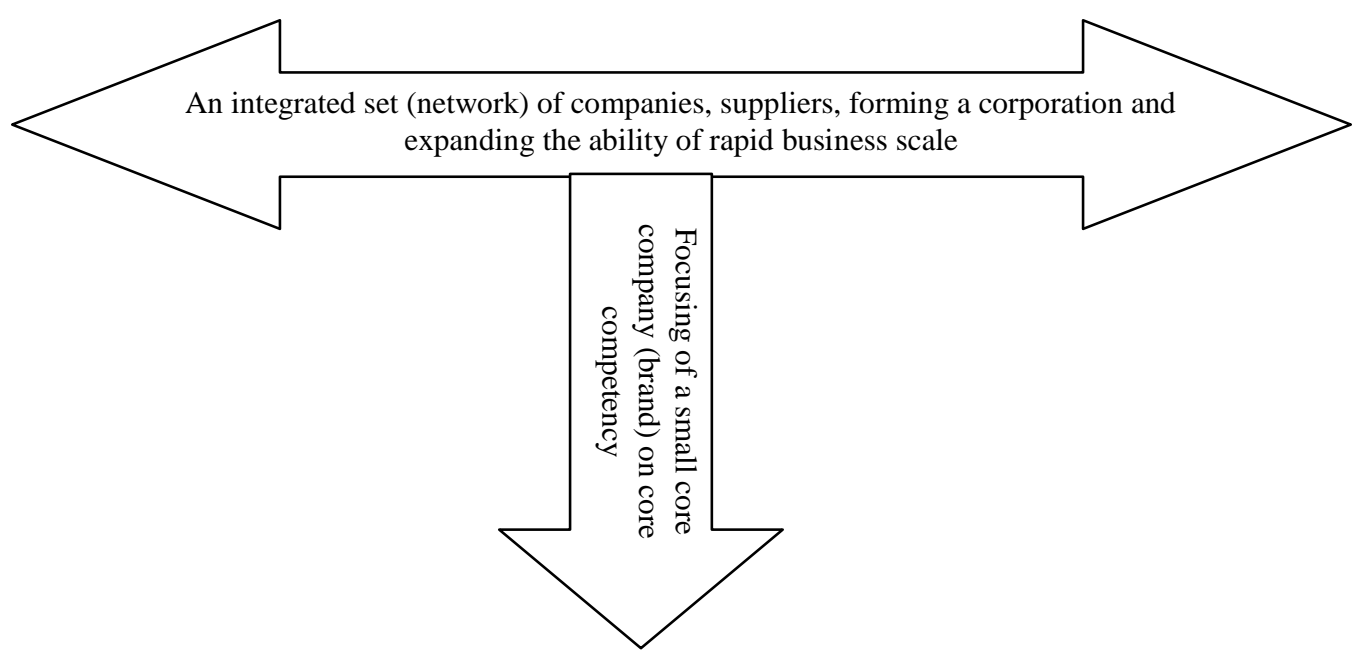

Figure 1. T-model of a network enterprise Source: Dzhalkibayev\&Musapirov, 2018 


\section{ENTREPRENEURSHIP AND SUSTAINABILITY ISSUES}

ISSN 2345-0282 (online) http://jssidoi.org/jesi/

2019 Volume 7 Number 2 (December)

http://doi.org/10.9770/jesi.2019.7.2(48)

The key competency of the managing company (integrator) becomes the function of coordinating the work of the supplier network, corporate management and marketing, and acting as a strategic architect and, in part, as controller. While the function of execution of customer orders, creation and maintenance of physical infrastructure, operating regulations and processes become remit suppliers are united in business network.

Authors call this T-model a nanocorporation. The nano-particle emphasizes the small size of the integrator; the second part of the word indicates the presence of many individual companies that are connected by a single concept and a common brand of the corporation. The horizontal line of the letter $\mathrm{T}$ means the use of opportunities and the scaling up of the corporation business, the vertical line means the integration of the core competence of the integrating company. Nanocorporation (lat. Nanos- gnome, dwarf, corpus- body, arch, whole) is a set of independent, specialized supplier companies with a small coordinating core link at the head (network enterprise). In nanocorporations, business processes are not so much directed inside the organization, but focus on integration with suppliers, on ensuring the coordinated work of companies and people involved in the process.

The term nanocorporation (nano-corporate, nano-core, nano-size corporate center) was proposed by Isobel Baylis and other authors in a series of reports by the consulting company KPMG "CFIO-Fast Forward 2035" (KPMG, 2013). According to KPMG researchers, the main advantage of nanocorporation is the small, low-cost and mobile center around which the business is built.

In the nanocorporation, the coordinating company ("network broker" in the terminology of Miles and Snow, 1986) has a dual role: its main competence as a manager is to provide a general direction of development and results for the entire network as a whole, including solving marketing and promotion issues brand group.

The other competence is the role of a network architect, that is, the selection of new suitable participants, their integration into a single network through related processes (negotiations, training, transfer of work standards). The core company coordinates the actions of many independent actors through the control of logistics flows, regular feedback, a group social network, etc. The integrator company takes responsibility for compliance with the required quality parameters and timely delivery of goods (including to external customers for the network). Partners, however, focus their efforts on operational activities within the established territory.

It is known that firms often experiment with their organizational boundaries in search of effective forms of conducting business: from vertical integration to full outsourcing and vice versa (Figure 2).

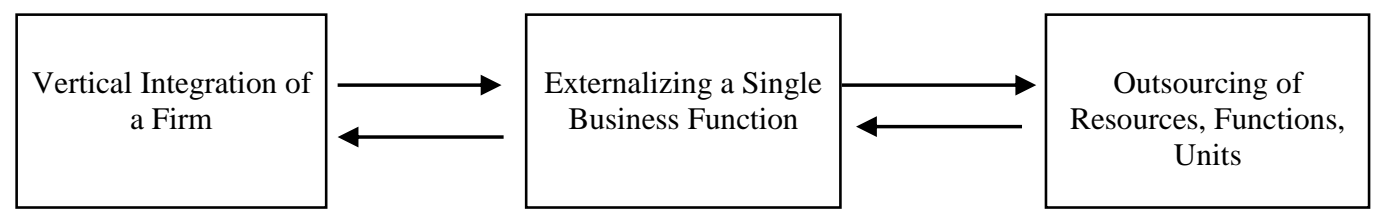

Figure 2. Change in the boundaries of the company

Source: compiled by the authors

The key variable in determining the boundaries of the company is the specificity of its assets, the narrowness of their application, when they have little value outside of specific transactions. The company's assets (within the RBV resource concept) include not only the company's personnel and physical assets (equipment, buildings, etc.), but also invisible assets such as the degree of intra-company horizontal integration of business processes, collective knowledge, regulatory forms of control andetc .. As the researchers note (Jermain at al., 2011), with high environmental uncertainty, the organic type of business structure, which has a more network, decentralized and informal character, is more effective. Vertical integration is more likely if the complexity of the product is 
large or a significant proportion of the specific resource in the total cost of the supply chain. According to the authors's statement, the focus on low costs has a significant impact on the level of outsourcing in production (Gray et al, 2009).

To improve the coordination of companies and optimize business processes in the network (supply chain), the following assumptions (hypotheses) were proposed (Figure 3):

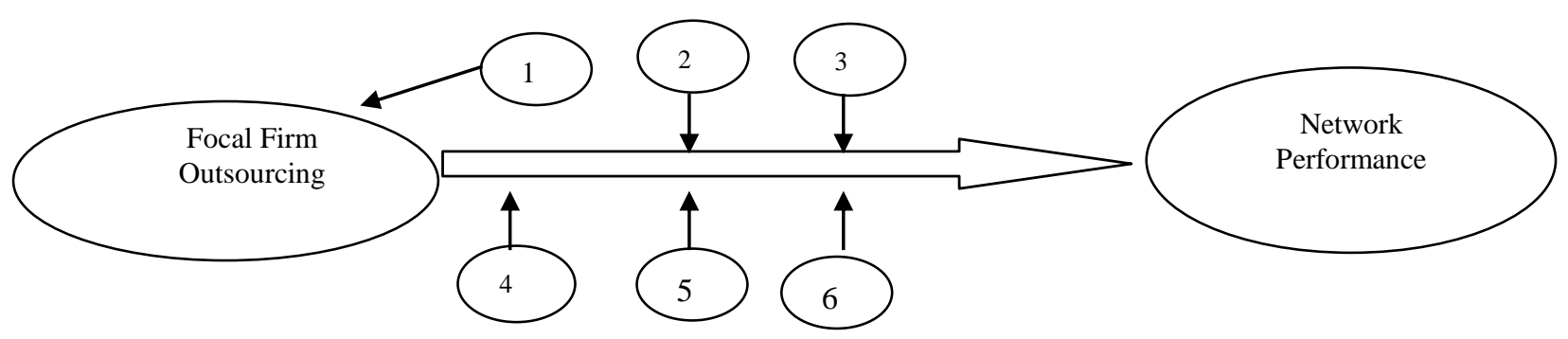

Figure 3. Focal Firm Outsourcing Link Model and Network Performance Source: compiled by the authors

1. The higher the "tuning" of the initial assets of the focal (core) company to fulfill the orders of various clients (low level of specificity of assets), the higher the level of outsourcing. In other words, the performance of network nanocorporations will decrease if the core company outsources functions with a high level of specificity of its assets.

2. The lower the specificity level of assets in the network, the higher the relationship between outsourcing and the overall performance of the network. This is consistent with the general conclusion of the theory of Transaction Costs Economics (TCE) that the more the assets in the supply chain are "tuned" to interact with a specific client (supplier), the less likely it is that the company will outsource this type of activity.

3. The higher the level of formal control in the network based on contracts (franchises and others), the more effective is the relationship between outsourcing of the focal company and the effectiveness of the network.

4. The more rationalized and standardized the activities of the focal company and, therefore, it has created effective «box solutions» for scaling, the higher the growth rate of the nanocorporation network. Kaizen methods are especially effective for standardizing operations and increasing the efficiency of processes in a focal firm.

5. The less physical assets and the operating component the focal company has, the more it concentrates on its core competency in managing the network and its development and, therefore, the more efficient the overall network performance.

6. The more centralized the decision-making on outsourcing in the focal company is, the faster decisions are made on outsourcing and the stronger the connection between outsourcing and network performance. 


\section{ENTREPRENEURSHIP AND SUSTAINABILITY ISSUES}

ISSN 2345-0282 (online) http://jssidoi.org/jesi/

2019 Volume 7 Number 2 (December)

http://doi.org/10.9770/jesi.2019.7.2(48)

\section{Research Methodology}

Three companies, introducing a network nanocorporation model and representing small and medium-sized businesses (SMEs) from various regions of Kazakhstan were taken for the study. These are Karavay KZ LLP (Shymkent), Bakhtiyar Avto LLP (Kyzylorda) and Domino Trade LLP from Aktau (Domino Home \&Horeca network). Some aspects of the nanocorporation model and the experience of its application have been considered previously (Dzhalkibaev \& Musapirov, 2018; Dzhalkibaev \& Musapirov, 2019)

As known, an adequate research methodology should be a reflection of the properties of the studied object. Considering the nature of the study (microlevel) and the emphasis on the managerial aspect, which is associated with the coordination of interests and motivation of people's actions, qualitative research methods were mainly used: case method, in-depth interviews, observation, comparison and others.

The case method is known in the scientific community and is considered effective in the study of poorly studied or new phenomena (Pettigrew, 1987). Such phenomena include the network form of business organization at the stage of origin and formation. The essence of the study is "rigorous studies of one case, which leads researchers to understand the new theoretical interdependencies, and also makes them, question existing ones" (Dyer\&Wilkins, 1991).

An individual in-depth (focused) interview is an important research method. The relevance and scientific value of a research tool is sufficiently substantiated in the literature. (Belanovsky, 2001). For research it is important that the interviewed leaders and top managers are those people who directly innovate their organizations. This allows to identify important subjective experiences and experiences that arise during the implementation of innovations.

The key elements of the stages of implementing managerial innovations have been previously identified and analyzed. Based on this analysis, an extensive questionnaire was developed for an in-depth interview (85 questions in three blocks), which covers all the necessary research questions.

A focused interview with leaders, owners, and managers of the enterprises was conducted based on the questionnaire. To achieve the validity of the study, the data was considered from both documentary analysis and external observation, as well as self-esteem of managers and owners of enterprises.

Formality of the obtained empirical data is achieved by collecting and analyzing data in a standardized way. The selection was made on the basis of the following criteria: companies that actually introduced managerial innovations had a pronounced entrepreneurial character and were at the stage of formation and rapid growth of the business.

Observation and analysis of the development processes of each company was carried out from 6 months to two years (longitude cases). The authors regularly recorded and systematized the main changes in the companies. Regular measurements of changes, analysis of problems of business growth and scaling are supposed to be carried out over the course of a number of years every 6-8 months.

The longitude character of the research allows to determine the causes of subsequent effects not limited to the identification of correlation dependencies; for example, periodic individual interviews have already shown that the internal locus of control (the entrepreneur's orientation toward himself and his own forces, rather than external factors or cases) precedes the scaling of the business and is one of the important reasons for the entrepreneurial orientation of companies. 


\section{ENTREPRENEURSHIP AND SUSTAINABILITY ISSUES}

ISSN 2345-0282 (online) http://jssidoi.org/jesi/

2019 Volume 7 Number 2 (December)

http://doi.org/10.9770/jesi.2019.7.2(48)

The study focuses on the launch of the process, means, on the emergence of a new form of business (entrepreneurial network). The selection of research objects was carried out from new, emerging forms of activity of individuals and organizations: the main stages of changes are monitored - both the entrepreneurs themselves and their environment and organizational context. The importance of studying the processes of the emergence of new forms of business was emphasized Davidsson and Wahlund (Davidsson, 2005).

The problem of generalizing and generalizing the findings to a wider set of phenomena has always been debatable in the applianceof the case study method. Therefore, the authors sought to find a reasonable balance between the detailed descriptive features of the practice of firms and the general development trends of small and mediumsized businesses. This allows to rise above individual cases and identify some stages in the development of network forms of entrepreneurial activity.

Cases were described on the basis of archival data for the period from 2016 to 2018, as well as more than 30 interviews with representatives of the business network, their suppliers, as well as experts conducted from April 2017 to July 2019. The sources, internal and external to the companies, were balanced.

Despite the specificity of the cases that have been taken under consideration, the rationale for the selection of research objects, the sequence of development and the relationship of assumptions (hypotheses), data collection methods are available and understandable to other researchers who decide to repeat the results and re-analyze the cases and materials.

\section{Results and discussion}

Domino Trade LLP (Domino Home \& Horeca network, Aktau) is engaged in retail and wholesale supply of tableware for home and restaurants in Kazakhstan. The owner and head of the franchise chain of stores is Davletov Zhalgas.

The family's business began in February 2014 in Aktau with the spouses from the opening of the "Everything for Home" retail store (the second in 2015). The turnover of two stores reached 6-9 million tenge per month, more than 20 sellers worked, the total sales area was $980 \mathrm{~m} 2$. The stores presented the widest range of dishes and textiles for the home of the national Evimnetwork (Turkish franchise).

The sharp devaluation of the national currency against the US dollar in August 2015 led to a crisis of the family business (growth of tenge from 180 to 270, then to 350 tenge per US dollar). All contracts for the supplied dishes, souvenirs, textiles were concluded in dollars, and goods were sold in tenge. The debt for the received, but not sold dishes of the Evim network has grown significantly and was not covered by the goods available.

As a result of anti-crisis measures, improvement of processes and flows by kaizen methods, ABC analysis, application of the Pareto principle (according to which $20 \%$ of products bring $80 \%$ of sales), the range was radically reduced by 23 product groups (including furniture, children's goods, etc.), various types of losses in the chain "warehouse-store-buyer" are reduced. The retail space and the number of sellers serving customers were significantly reduced (on average by 50\%). This all made it possible to raise the level of sales conversion from $6.2 \%$ to $30 \%$, and to reduce several times the sales area and staff. 


\section{ENTREPRENEURSHIP AND SUSTAINABILITY ISSUES}

ISSN 2345-0282 (online) http://jssidoi.org/jesi/

2019 Volume 7 Number 2 (December)

http://doi.org/10.9770/jesi.2019.7.2(48)

Two important strategic decisions were made:

(1) The B2B sector is defined as the main niche: it is cafes, restaurants, hotels, guest houses, supermarkets, companies specializing in catering, etc. The study of their requests allowed us to establish the optimal list and volume of goods that must be ordered from wholesale suppliers.

(2) Concentration of forces on key competencies - the creation and management of a corporate network, the saturation of its commodity supplies; to outsource the functions of storage, delivery and, most importantly, the sale of goods, that is, refuse to own stores.

To create a franchise, a "boxed solution" for the function of selling goods was prepared (packaged). This is a store or warehouse store with an area of 40-70 m2 with an optimal set of products: tableware, for cooking, knives and kitchen accessories, tables and chairs, covers for restaurants, etc. On the basis of the franchise agreement, each member of the network was given a set of benefits for managing the store (including operating standards), as well as providing training, internships and testing of personnel, marketing support.

As of December 31, 2018, over 1.5 years, on a franchise basis, 22 stores of the accepted box format were opened in all major cities of Kazakhstan. This made it possible to significantly increase sales, receive more and more privileges and discounts from wholesale suppliers, and set lower prices and shorter delivery times than competitors.

On the basis of a network of 22 stores and regional warehouse stores, it is planned to open an online store in 2019 with delivery of day-to-day orders (ideally in one hour). The combination of the best price in the region and fast delivery allows the network to become the future leader in e-commerce

In 2007-2016, Karavay KZ LLP from Shymkent has been developing in the middle price segment as a network of dining rooms with home cooking, focused on quality (product differentiation strategy).

As the business grew, it became increasingly difficult to manage a larger company. A leadership crisis arose: further development of the network required the abandonment of manual control "according to the situation" (ad hoc) and the introduction of regular management tools. There was a need to implement effective operating systems. An understanding has come that competition is carried out not only in terms of price, assortment and quality of dishes, but also in internal operating systems.

Changes in the company were carried out in two stages:

- from 2015 to August 2017, improvements were made to operating systems and working standards, automation and informatization, optimization of business processes in order to reduce losses and control costs; standard operating procedures (SOPs) were developed and implemented - maintenance, cleaning the room, table, washing dishes, behavior in different situations.

- Since September 2017, the company has completely switched to work in the format of nanocorporation and the implementation of a new cost leadership strategy for it. The average check was reduced from 1200 tenge to 1000 tenge, then 800 tenge and 500 tenge.

As of January 2019, Karavay.KZ LLP had 9 points of sale with a total number of 50 people: seven points work in a new format (number of employees 2 people per point), 2 points, including a food preparation workshop, worked in a traditional format (average check - 1200 tenge). 


\section{ENTREPRENEURSHIP AND SUSTAINABILITY ISSUES}

ISSN 2345-0282 (online) http://jssidoi.org/jesi/

2019 Volume 7 Number 2 (December)

http://doi.org/10.9770/jesi.2019.7.2(48)

The company has standardized all work processes, the range of dishes has been reduced from 280 to $45-50$ items, including 14 items - the main popular dishes. Outsourcing has translated the production of a significant part of the types of dishes (manti, dumplings, etc.) and ingredients, as well as the delivery of dishes - both for their points and for B2B customers. At the core (brand) company they left distribution of products, packaging and packaging of dishes (in the central workshop), planning and marketing (search and attraction of B2B category customers).

The goal for the coming year is to reach 500 million tenge in the revenue of all types of products and open 15 more outlets in Kazakhstan operating in a new format. The emphasis is on work in the B2B sector (schools, hospitals, factories, construction sites, etc.).

The third company - Bakhtiyar-Avto LLP from Kyzylorda (head -Kudaibergenov Bakhtiyar) provides services for installing gas equipment on cars and selling gas-cylinder equipment (GCE) for consumers.

Since 2016, the company has been an official representative for the sale of components of GCE in the South Kazakhstan region and Astana. The total number of employees is 18 people, including 10 people - installers of gas equipment.

At the moment, the company operates in the market of three large cities using the B2C system (services for installing GCE for cars of individuals and legal entities as final consumers) and buyers of B2B equipment (commercial organizations, GCE installers).

The company has completely revised and improved work operations and updated standards. As a result, it was possible to maximumly reduce the time for conversion of the car from 8 hours to 1.5 hours (in the absence of any problems in the car itself). This is the best result in this segment in Kazakhstan.

The company carries out direct deliveries of gas equipment from manufacturing plants in Italy, Poland and Belarus, as well as through KazTechnoGas LLP (Uralsk). Fundamental changes began in the company with the introduction of a continuous process improvement system (kaizen) at the enterprise and the creation of an effective workplace using the well-known 5S methodology.

The product range was sharply reduced in sales: at the first stage, out of 250 components, about 100 items were left; the task is to switch to the sale of only the most popular goods and reduce the number of products sold to the 15 most popular items.

The company's events in September-December 2017 included staff optimization (reducing staff from 50 to 30 , then to 18) and halving overhead costs. As a result, the overall efficiency of the customer service system increased by 5 times, the installation time of GCE on one car was reduced by 7 times

At the end of 2018, compared with 2017, revenues increased several times. The goal was to reach a turnover of 1 billion tenge by the end of the year, actively replicating successful business by entering the markets of Almaty, Astana, Pavlodar and other cities.

Summarizing the three cases, it can be said that the process of deriving the function of selling goods outside the company for outsourcing (externalization) has five stages recorded in the transactions of three companies (table $1)$. 
Table 1. The generalized process of externalization of the function of selling goods (services)

\begin{tabular}{|c|c|c|c|c|c|c|}
\hline Stage I & \multicolumn{2}{|c|}{ Stage II } & \multicolumn{2}{|r|}{ Stage III } & Stage IV & Stage V \\
\hline Basicpremise & \multicolumn{2}{|c|}{ Incubation period } & \multicolumn{2}{|c|}{$\begin{array}{l}\text { Conclusion of a function to outsourcing } \\
\text { or purchasing a service in the market }\end{array}$} & Collaboration building & Network integration \\
\hline \multicolumn{7}{|c|}{ Process description } \\
\hline \multicolumn{2}{|c|}{$\begin{array}{c}\text { Making strategic decisions on } \\
\text { key competencies and } \\
\text { outsourcing of functions } \\
\text { (work) }\end{array}$} & \multicolumn{2}{|c|}{$\begin{array}{l}\text { Provision of in-house } \\
\text { changes and packaging } \\
\text { of the optimal "boxed } \\
\text { solution" for replication }\end{array}$} & $\begin{array}{c}\text { Conclusion of function } \\
\text { outside or purchase in } \\
\text { the market }\end{array}$ & $\begin{array}{l}\text { Redefining and clarifying } \\
\text { responsibilities, debugging } \\
\text { interaction, understanding } \\
\text { cooperation of interests }\end{array}$ & $\begin{array}{c}\text { Network collaboration } \\
\text { based on contracts, internal } \\
\text { communications, informal } \\
\text { interaction }\end{array}$ \\
\hline
\end{tabular}

\section{Goal}

\begin{tabular}{|c|c|c|l|l|}
\hline $\begin{array}{c}\text { Finding a niche } \\
\text { segment and core } \\
\text { competence of the } \\
\text { company }\end{array}$ & $\begin{array}{c}\text { Business scaling, } \\
\text { rapid growth in the } \\
\text { level of sales of goods } \\
\text { (services) }\end{array}$ & $\begin{array}{c}\text { Finding an effective seller of } \\
\text { goods (services) in the region, } \\
\text { including among employees }\end{array}$ & $\begin{array}{l}\text { Establishment of } \\
\text { effective cooperation, } \\
\text { achievement of } \\
\text { synergy of efforts }\end{array}$ & $\begin{array}{l}\text { Strengthening and } \\
\text { deepening cooperation, } \\
\text { preventing problems }\end{array}$ \\
\hline
\end{tabular}

\section{Formal Milestones}

\begin{tabular}{|c|c|c|c|c|}
\hline $\begin{array}{c}\text { Strategic decisions } \\
\text { taken }\end{array}$ & BoxSolutionModel & $\begin{array}{c}\text { Franchise agreement and contract } \\
\text { for the supply of goods } \\
\text { (provision of services) }\end{array}$ & $\begin{array}{c}\text { Model of contract prices, } \\
\text { rights and obligations }\end{array}$ & $\begin{array}{c}\text { Model of contract prices, } \\
\text { rights and obligations }\end{array}$ \\
\hline
\end{tabular}

Source: compiled by the authors

In terms of management, the implementation of the concept of nanocorporation has enabled integrator firms to abandon the accumulation and control of tangible assets. It focused on strategic and marketing planning, corporate management and brand promotion. This allowed to reduce the number of employees to 3-7 people. Intra-firm changes and the creation of a "boxsolution" made it possible to replicate the business and create an extensive network (table 2).

Table 2. Summary of three network enterprises

\begin{tabular}{|c|c|c|c|c|c|c|}
\hline & $\begin{array}{c}\text { Firms using the } \\
\text { nanocorporation } \\
\text { model }\end{array}$ & $\begin{array}{c}\text { Industry and location of } \\
\text { the core (focal) company }\end{array}$ & $\begin{array}{c}\text { The number of } \\
\text { agents in the } \\
\text { network }\end{array}$ & $\begin{array}{c}\text { Numberoffranc } \\
\text { hisingagreeme } \\
\text { nts }\end{array}$ & $\begin{array}{c}\text { Joint (cross) } \\
\text { ownership of } \\
\text { assets }\end{array}$ & $\begin{array}{c}\text { Number of full-time employees } \\
\text { of the central (focal) company }\end{array}$ \\
\hline 1 & LLP Karavay KZ & publiccatering, Shymkent & 9 & 7 & 2 & 6 \\
\hline 2 & LLP "DominoTrade" & $\begin{array}{c}\text { wholesale and retail trade } \\
\text { Aktau, Almaty }\end{array}$ & 23 & 22 & 6 & 2 \\
\hline 3 & Bakhtiyar-Avto LLP & $\begin{array}{c}\text { maintenanceservices } \\
\text { Kyzylorda }\end{array}$ & 6 & 6 & 0 & 3 \\
\hline
\end{tabular}

Source: as of March 31, 2019, compiled by the authors

The survey of change leaders showed that achieving operational efficiency and continuous improvement of operations is not an easy task of stage 1 changes. Tough decisions must be made to change the organizational structure, internal and external communications, standardize operating procedures, and take measures to involve staff (kaizen). 


\section{ENTREPRENEURSHIP AND SUSTAINABILITY ISSUES}

ISSN 2345-0282 (online) http://jssidoi.org/jesi/

2019 Volume 7 Number 2 (December)

http://doi.org/10.9770/jesi.2019.7.2(48)

At the second stage, it is understood that although optimization and operational efficiency improve the company's performance, they cannot provide a long-term competitive advantage (other companies have also implemented best practices). One operational efficiency is not enough - it is important to have a unique strategy,do something different than others. The business model of nanocorporation has given entrepreneurs such a perspective.

For Kazakhstani companies, the problem of business growth is compounded by the fact that they cannot fully utilize the economies of scale due to the small size of the local market compared to, for example, China, Russia or Uzbekistan (Islamgaleyev, 2018; Labunska et al, 2019; Pukala, 2016). In the vast territory of Kazakhstan with an area of 2.7 million $\mathrm{km} 2$, only 18 million people live. Population and markets are localized in several large cities, roads and railways are stretched and imperfect. After Kazakhstan joined the World Trade Organization and with the free flow of goods, capital and labor within the framework of a single Eurasian Economic Union, competition only intensified.

In addition to achieving operational efficiency and the strategic selection of a business model, entrepreneurs learn to identify and overcome considerable obstacles in the mental sphere: expand their consciousness and planning horizon, set ambitious and elusive goals to go beyond the national market. In order to develop the studied networks, the task is to penetrate the global market. So, in the coming years, the Domino home \&horeca network is planned to enter the markets of Russia, Uzbekistan and China.

Making a general review of company research, it can be said that the following results were obtained:

1. The lower the level of specificity of assets, as the standard "all for home" stores in Domino Trade LLP, the higher the level of outsourcing (all stores and the function of selling goods are transferred to network participants). And vice versa, due to the fact that the effectiveness of the network nanocorporation will suffer, the core company Karavay.KZ LLP did not outsource its specific asset - the central department for the preparation and packaging of dishes.

2. The rapid way has been shown for the growth and scaling of small and medium-sized businesses, if an optimal "boxed solution" has been prepared for its replication, as well as entrepreneurial intentions focused on significant growth have been formed. Another way for small businesses to compete is to stay on the level of survival or simply break up. This is consistent with the position of organizational ecology that the selection mechanism in a competitive environment is more powerful than simply adapting to environmental changes (Radaev, 2005).

3. The viability of the network model of nanocorporation was tested and the problems that arise at each stage of its implementation in the face of low solvency of the population, a slowdown in economic growth and a significant degree of uncertainty (including the unstable rate of the national currency) are revealed.

4. A small core center (focal firm) can effectively manage network nanocorporation by focusing on core competencies and outsourcing most of the traditional functions along with physical assets and human resources.

5. A franchise network of nanocorporations allows to rapidly scale a business if the actor company has developed and successfully applied standard operating procedures and models, marketing strategies, and has sufficient entrepreneurial experience and level. Effective "boxed" solutions and formal control based on a franchise agreement in all three nanocorporations have shown its effectiveness for network growth.

6. The rapid growth of small and medium-sized businesses, which have an entrepreneurial character, positively correlates with both centralized decision-making on outsourcing units and the personal transformation 


\section{ENTREPRENEURSHIP AND SUSTAINABILITY ISSUES}

ISSN 2345-0282 (online) http://jssidoi.org/jesi/

2019 Volume 7 Number 2 (December)

http://doi.org/10.9770/jesi.2019.7.2(48)

of the leader and his team; the latter is associated with the transfer of the intentions and visions of actors from a local to a global focus (perspective), with the development and setting of ambitious, elusive goals.

7. Small companies can successfully compete with large businesses through the creation and development of networked entities.

What are the obstacles and limitations to the implementation and dissemination of network nanocorporations? Firstly, unlike bureaucratic, team relations within the company or formal contractual relations between them, inter-company coordination is characterized mainly by an organic or informal social system based on the exchange of social products. Trust, common cultural and age affiliation, prestige, social rootedness of the practice, control through business standards, culture, moral obligations, etc. are of great importance. This requires the development of social skills from the leader and team of the core company, taking measures to strengthen trust and informal relationships.

Secondly, the regional external environment in which network participants operate can influence the internal environment of these small enterprises. They can actually they can merge with local interests and specifics. It is necessary to develop systems of diverse network communications, modern control and audit using appropriate information technologies.

Thirdly, any cost-effectiveness and structural compliance alone do not guarantee success. Against innovators, the principle of "liability of newness", formulated by A. Stinchcombe, dates back to the mid-1960s. Usually, the frequency of creating new forms of business is initially low, although the market niche is still relatively free.

\section{Conclusions}

The fluctuating needs of customers are becoming more personalized and can be satisfied only by those organizations that themselves are constantly changing. According to KPMG experts (Baylis, KPMG, 2013: 7), in the future, nanocorporations and pop-ups will become the dominant organizational structure and in fact the only option to remain competitive. Large bureaucratic "modern organizations ... will have to evolve, otherwise they will disappear." They are too expensive, too difficult to change, and unable to cope with the growing needs of consumers."

The development of the companies that have been reviewed is based on the cost leadership strategy, which allows the competitive advantages of network structures operating in conditions of limited solvent demand to be most strongly manifested.

Based on network coordination and analytics, it is possible in the future to develop a holistic ecosystem (such as the Chinese Alibaba), which within itself coordinates the actions of many players. This ecosystem allows network members to be more competitive and customer-oriented, significantly reducing their costs compared to traditional firms.

Thus, a small company of an entrepreneurial nature can become national in a relatively short period by attracting the resources of network participants to ensure better quality and price. On the basis of such cases, collected empirical material sufficient to theoretically generalize the experience of managing network nanocorporation and study its evolution. The study is built as longitude and authors will continue to track the further development of these network entities with a frequency of 6-8 months. 


\section{ENTREPRENEURSHIP AND SUSTAINABILITY ISSUES}

ISSN 2345-0282 (online) http://jssidoi.org/jesi/

2019 Volume 7 Number 2 (December)

http://doi.org/10.9770/jesi.2019.7.2(48)

\section{References:}

Amraoui, B., Ouhajjou, A., Monni, S., El Amrani El Idrissi, N., Tvaronavičienè, M. (2019). Performance of clusters in Morocco in the shifting economic and industrial reforms. Insights into Regional Development, 1(3), 227-243. https://doi.org/10.9770/ird.2019.1.3(4)

Baylis, I. Nano-corporate, (2013), KPMG, CFIO-FastForward http://www.acca.lt/content/dam/acca/global/PFDmemberscpd/AFF/KPMG\%20Fast\%20Forward\%20Nano\%20Corporate.pdf

Belanovsky S. 2001. Individual in-depth interview. Textbook. Moscow: Nikkolo-Media, 320 p. [in RU]

Bogomolov, A.B, Nevezhin, V.P., Chagovets, L.O. (2018). Using econometric modeling in likelihood assessing of investment activity risks. IEEE First International Conference on System Analysis \& Intelligent Computing (SAIC-2018)) Kyiv, Ukraine 08-12 October 2018, IEEE Catalog Number: CFP18SUA-CDR, Institute of Electrical and Electronics Engineers Inc. https://doi.org/10.9770/ird.2019.1.1(1)10.1109/SAIC.2018.8516898

Damanpour, F. and Aravind, D. (2012). Managerial innovation: conceptions, processes, and andantecedents. Management and Organization Review, 8(2), 423-454.

Davidson, P. (2005). Researching Entrepreneurship, Springer, US, pp.31-38.

Dedeurwaerdere, T., Krishna, V., Pascual, U. (2007). An evolutionary institutional approach to the economics of bioprospecting $\mid$ In: Biodiversity Economics: Principles, Methods, and Applications, Cambridge University Press (UK), pp.417-445.

Dellis, K., Karkalakos, S., \& Kottaridi, C. (2016). Entrepreneurship Targeting Policies, Technological Growth, and Unemployment. Journal of Eurasian Economic Dialogue, 1(6), 19-39.

Djilkibaev, J.V., Musapirov, Kh.K. (2018). Innovative business model of nanocorporation: theoretical prerequisites and experience of implementation in Kazakhstan enterprises. The Journal of Economic Research \& Business Administration 3(125), Al-Farabi Kazakh National University ISSN 1563-0358. [RU]

Djalkibaev, J.V., Musapirov, Kh.K. (2019). Creation of nano-corporation based on outsourcing and franchising: experience of a Kazakhstan company. The Journal of Economic Research \& Business Administration 1(127). Al-Farabi Kazakh National University. ISSN 1563-0358 eISSN 2617-7161.

Dyachenko, Y., Nenkov, N., Petrova, M., Skarga-Bandurova, I., Soloviov, O. (2018). Approaches to Cognitive Architecture of Autonomous Intelligent Agent. Biologically Inspired Cognitive Architectures, Elsevier, 26, p.130-135.

Dyer W. G., Wilkins A. (1991). Better stories, not better constructs, to generatebetter theory: A rejoinder to Eisenhardt, Academy of Management Review, 16(3), 613-619.

Eddelani, O., El Idrissi, N. E., Monni, S. (2019). Territorialized forms of production in Morocco: provisional assessment for an own model in gestation. Insights into Regional Development, 1(1), 6-18. https://doi.org/10.9770/ird.2019.1.1(1)

Galaso, P., \& Kovárík, J. (2018). Collaboration Networks and Innovation: How to Define Network Boundaries. Journal of Eurasian Economic Dialogue, 3(2), 1-17.

Germain R., Krotov K., Fedotov J. (2011). Outsourcing and vertical integration: proposals for research based on organizational theory, Russian Journal of Management, 9(2), 93-108. [RU]

Grandori, A., Soda, G. (1995). Inter-firm networks: Antecedents, mechanisms and forms. Organization Science, 16(2), $183-214$.

Gray, J.V., Roth, A.V., Tomlin, B. (2009). The influence of cost and quality priorities on the propensity to outsource production. Decision Sciences 40: 697-726. 


\section{ENTREPRENEURSHIP AND SUSTAINABILITY ISSUES}

ISSN 2345-0282 (online) http://jssidoi.org/jesi/

2019 Volume 7 Number 2 (December)

http://doi.org/10.9770/jesi.2019.7.2(48)

Hlushko, O., Gryshova, I., Shcherbata, M. (2015). Enterprises' economic sustainability assessment on the basis of performance indicators. Economic Annals-XXI, 155(11-12), 82-86.

Islamgaleyev, A. (2018). Target client group analysis at "Kazpromkomplex" LLP. Minzu University of China «Scientific research of the SCO countries: synergy and integration» June 29-30, pp.29-40, ISBN 978-5-905695-70-4. Beijing

Islamgaleyev, A.H., Uruzbayeva, N.A. (2018). Using a customer-oriented approach in sales management in the metal trading market of the Republic of Kazakhstan. Vienna: Premier Publishing s.r.o. 184 p.

Jones, C., Hesterly, W. S., Borgatti, S. P. (1997). A general theory of network governance: Exchange conditions and social mechanisms. Academy Management Review, 22(4), 911-945.

Kolodiziev, O.M., Boyko, N.O. (2015). Formation of customer capital management strategies at engineering enterprise. Actual Problems of Economics, 174(12), 168-180

Koval, V. Pukała, R. (2017). Implementation of Regulatory Policy in Economic Activity: Development of the Institute Regulatory Impact Assessment. Economics. Ecology. Socium, 1(1), 24-32.

Labunska, S., Karaszewski, R., Prokopishyna, O., Iermachenko, I (2019). Cognitive analytical tools for cost management of innovation activity. Problems and Perspectives in Management, 17(1), 395-407. http://dx.doi.org/10.21511/ppm.17(1).2019.34

Hemant T., Kevin M., (2018). The End of Scale. Sloan Management Review, 09.02.2018, Magazine: Spring 2018.

Miles, R. and Snow, C. (1986). Organizations: new concepts for new forms. California Management Review, 28(2), 68-73

Nenkov N., Dimitrov G., Dyachenko Y., Koeva K. (2016). Artificial intelligence technologies for personnel learning management systems. In R. Yager, V. Sgurev, M. Hadjiski, \& V. Jotsov (Eds.), 2016 IEEE 8th international conference on intelligent systems (pp. 189-195).

New York: IEEE. https://doi.org/10.10.1109/IS.2016.7737420

Nenkov, N., Sushchenko, O., \& Dyachenko, Yu. (2017). Role of chief information officer within the system of human resource development in service organizations (tourism). Economic Annals-XXI, 165(5-6), pp. 97-103. https://doi.org/10.21003/ea.V165-20

Nieves J., Osorio J. (2018). Using information technology to achieve management innovation. Academia Revista Latinoamericana de Administración https://doi.org/10.1108/ARLA-02-2016-0037

Nielsen, Ch. and Lund, M. (2018). Building Scalable Business Models. Sloan Business Review https://sloanreview.mit.edu/article/buildingscalable-business-models

Petrova, M., Sushchenko, O., Iryna Trunina, Nadiya Dekhtyar. Big Data Tools in Processing Information from Open Sources. IEEE First International Conference on System Analysis \& Intelligent Computing (SAIC-2018)) Kyiv, Ukraine 08-12 October 2018, IEEE Catalog Number: CFP18SUA-CDR, ISBN: 978-1-5386-7195-5, pp.256-260, Institute of Electrical and Electronics Engineers Inc., https://doi.org/10.1109/SAIC.2018.8516800

Pettigrew, A. M. (1987). Context and action in the transformation of the firm. Journal of Management Studies, 24(6), 649-670.

Ponomarenko, V., Gontareva, I. (2017). The system of causal connections between entrepreneurial activity and economic development. Economic Annals - XXI, 165(5-6), 4-7. https://doi.org/10.21003/ea.V165-01

Prodani, R., Bushati, J., Andersons, A. (2019). An assessment of impact of information and communication technology in enterprizes of Korça region. Insights into Regional Development, 1(4), 333-342. https://doi.org/10.9770/ird.2019.1.4(4)

Pukala, R. (2016). Use of neural networks in risk assessment and optimization of insurance cover in innovative enterprises. Engineering Management in Production and Services, 8(3), 43-56).

Pukala, R., Kaidarova, S., Makysh, S., Zhumanov, K. (2018). China and Asia: Some Economic Aspects. (2018). Conference: 31st International-Business-Information-Management-Association. Milan, ITALY APR 25-26, 2018. INNOVATION MANAGEMENT AND EDUCATION EXCELLENCE THROUGH VISION 2020, VOLS I -XI, Pages: 91-95 


\section{ENTREPRENEURSHIP AND SUSTAINABILITY ISSUES}

ISSN 2345-0282 (online) http://jssidoi.org/jesi/

2019 Volume 7 Number 2 (December)

http://doi.org/10.9770/jesi.2019.7.2(48)

Radaev, V. V. (2005). Population ecology of organizations: how there is a variety of organizational forms, Russian Journal of Management, 3(2) [in RU]

Razminienè, K, Tvaronavičienè, M. (2018). Detecting the linkages between clusters and circular economy. Terra Economicus, 16(4):50-65 https://doi.org/10.23683/2073-6606-2018-16-4-50-65

Tumalavičius, V., Veikša, I., Načisčionis, J., Zahars, V., \& Draskovic, V. (2017). Issues of the state and society security (part i): ensuring public security in the fight against crime. Journal of Security \& Sustainability Issues, 6(3). http://doi.org/10.9770/jssi.2017.6.3(7)

Tvaronavičienè, M. (2017). Clusters, innovations and energy efficiency: if relantionship could be traced. Marketing and Management of Innovations, 2: 382 - 391 http://doi.org/10.21272/mmi.2017.2-35

Tvaronavičienė, M., Razminienė K. (2017). Towards competitive regional development through clusters: approaches to their performance evaluation. Journal of Competitiveness, 9(4): 133 - 147. https://doi.org/10.7441/joc.2017.04.09

Khayrolla MUSSAPIROV, PhD student, MBA, graduated from Moscow state University, Russia; Senior Lecturer of the Higher school of business of Almaty Management University on courses "Operational management", "Strategic management"; consultant, doctorial student of Business Administration in Almaty Management University. Research interests: entrepreneurship, methodological issues of business research (including small and medium business), managerial and organizational innovation, innovation process, nano-corporation.

https://orcid.org/0000-0002-8507-3158

Jeksen JALKIBAEYEV, MBA, Senior Lecturer of the Higher school of business of Almaty Management University. He is an ISO, BSC, HRM-Europe certified professional with diversified credentials. Some of them are: Advisor to the chairman of JSC «National wealth fund» Samruk-Kazyna», Advisor to the chairman of «BI Group development» holding, Deputy Chairman of JSC «National Innovation Fund», Advisor to the Minister of Industry and Trade of the Republic of Kazakhstan. Author of the management effectiveness development training programs: Mind-maps, Silva method, Time management: «Automated workplace of the manager», Effective mind-thinking techniques. Currently is a business coach and senior lecturer at the Almaty Management University. Research interests: entrepreneurship, managerial and organizational innovation, innovation process, nano-corporation.

https://orcid.org/0000-0003-4476-358X

Gulnara KURENKEYEVA, Dean of Graduate School of Business, Professor, PhD in economics, Almaty Management University, Kazakhstan. She is the Head of corporate entrepreneurship and innovation laboratory at AlmaU, supervises doctoral students at $\mathrm{PhD}$ and DBA programmes. Also, she is a scientific editor of the translation of the world's bestsellers books and textbooks in the field of business and management into Kazakh language within the framework of the national human capital development program. Research interests: entrepreneurship, corporate innovation and entrepreneurship; management in health care; service management in health care.

https://orcid.org/0000-0001-6188-045X

Aizhan KADIRBERGENOVA, Master of Mining, Executive MBA, Doctorial student of Business Administration, PhD student; Director of Department of Doctoral Programs, Senior Lecturer. Research interests: management, psychology, HR, business.

https://orcid.org/0000-0001-5813-902X 


\section{ENTREPRENEURSHIP AND SUSTAINABILITY ISSUES}

ISSN 2345-0282 (online) http://jssidoi.org/jesi/

2019 Volume 7 Number 2 (December)

http://doi.org/10.9770/jesi.2019.7.2(48)

Mariana PETROVA, Professor, D.Sc in Physics and Mathematics, Assoc.Prof. St. Cyril and St. Methodius University of Veliko Tarnovo, Bulgaria; Professor Economics and Management in Department of Management, ISMA University, Riga, Latvia. Research interests: management of IT processes, project and services, business administration, modern information systems and innovations, knowledge economy, sustainable development.

ORCID ID: https://orcid.org/0000-0003-1531-4312

Lyailya ZHAKYPBEK, PhD, al-Faraby National University, Almaty, Diploma in Economical Science, Kazakh Academy of Management, Almaty, Dean of School of Management of Almaty Management University. Research interest: Management in education and in economics.

https://orcid.org/0000-0001-8082-5042

Register for an ORCID ID:

https://orcid.org/register

Copyright (C) 2019 by author(s) and VsI Entrepreneurship and Sustainability Center

This work is licensed under the Creative Commons Attribution International License (CC BY).

http://creativecommons.org/licenses/by/4.0/

(c) (7) Open Access 